\title{
Chemistry of 1, 2, 4-Triazole: A Review Article
}

\author{
Jawad K. Shneine ${ }^{1}$, Yusra H. Alaraji ${ }^{2}$ \\ Department of Chemistry, College of Science, Al-Nahrain University, Al-Jadria, Baghdad, Iraq
}

\begin{abstract}
Triazole was first synthesized over a century ago, but still attracts attention of chemists, biologists, technologists and other specialists. In recent years, antiviral, anti-inflammatory, anti-fertility, anti-tubercular activity, antimicrobial activities, anti-cancer and anti-corrosion properties of triazoles have been published. This review aims to describe the structures, synthesis, reactions and spectral properties of triazoles for highlighting the future applications in several bioactive phenomena and analytical uses.
\end{abstract}

Keywords: 1, 2, 4-Trizole, Thiole Derivatives, Applications of 1,2,4-Triazole, Synthetic approaches of 1,2,4-triazole.

Content:

1. Introduction

2. 1,2,4-Triazole

3. Structural Properties of Triazoles

3.1. Aromaticity and Stability

3.2. Tautomerism in Triazoles

3.2.1. Tautomerism in 1,2,3-Triazoles

3.2.2. Tautomerism in 1,2,4-Triazoles

3.2.3. Tautomerism in Substituted-1,2,4-Triazoles

4. Spectroscopy of 1,2,4-Triazole

4.1. Ultraviolet Spectroscopy (UV)

4.2. Infrared Spectroscopy (IR)

4.3. Nuclear Magnetic Resonance (NMR)

4.4. Mass Spectrometry (MS)

5. Synthetic Methods of 1,2,4-Triazoles

5.1. From Carboxylic Acid Hydrazide

5.2. From 1,3,5-Triazine

5.3. From Oxazole

5.4. From Thiosemicarbazide

5.5. From Urea

5.6. From Acid Chloride

6. Biological Activities

6.1. Agricultural Applications

6.2 Pharmacological Applications

6.2.1. Antibacterial Activities

6.2.2. Antifungal Activities

6.2.3. Anticancer and Antitumor Activities

6.2.4. Anti-inflammatory Activities

6.2.5. Anticonvulsant Activities

6.2.6. Antiviral Activities

6.2.7. Antitubercular Activities

6.2.8. Antioxidant Activities

7 Industrial Applications

\section{Introduction}

Heterocyclic chemistry is a separate field of organic chemistry with long history and future prospects. Life is totally dependent on the heterocyclic compounds, such as purine and pyrimidine bases (building unit of DNA and RNA). Now a days, the heterocyclic chemistry brings reagents and synthetic methods of its own usual activity in synthesis of drugs [1], pesticides [2] and detergents [3], as well as into the correlated fields such as biochemistry [4], polymers [5, 6], Dyes [7, 8], and material sciences [9].

\section{1, 2, 4-Triazole}

There is significant and continuous concern in the chemistry of five-member N-heterocycle compounds, mainly tetrazole (CH2N4), triazoles (C2H3N3), and their substituted derivatives [10]. Five-membered nitrogen heterocycle compounds are important structural fragments and considered as biologically active compounds [11-16], corrosion inhibitors [17], pesticides [18], dyes [19], acidbase indicator [20], and other industrial chemicals [21]. At 1885, Bladin was the first science who gave the name of (triazole) to the carbon nitrogen ring system (C2N3H3) and described triazoles' derivatives [22].

Triazole exists as two isomers, 1,2,3-triazoles and 1,2,4triazoles, as shown in (Fig. 1) [10].

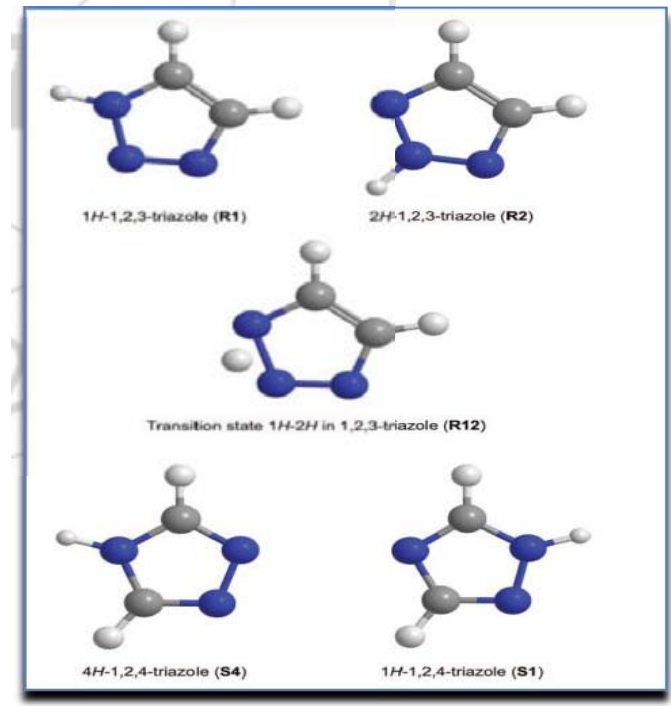

Figure 1: Triazole tautomers (R1, R2, S1 and S4) and transition state (R12) [10].

1, 2, 3-triazole is used as antibacterial [23-26], antifungal [26, 27], antioxidant [28], anti-malarial and anti-leishmanial drugs [29, 30]. 1, 2, 4-triazole is used as a factor in drug structures even more than 1,2,3-isomer. The chemical industry got attention in the synthesis of both simple and fused triazole systems [31-36] after finding that the certain triazoles have the ability of inhibiting the fog formation in photographic emulsions [37], and some others being useful 


\section{International Journal of Science and Research (IJSR) \\ ISSN (Online): 2319-7064}

Index Copernicus Value (2013): 6.14 | Impact Factor (2014): 5.611

herbicides and convulsants.

\section{Structural Properties of Triazoles}

\subsection{Aromaticity and Stability}

Aromaticity is the main reason of stability of triazole nucleus. An aromatic sextet is formed by donation of one $\pi$ electron from each atom connected by double bonds, in addition of the remaining two electrons from a nitrogen atom [38]. Also, triazole nucleus is stabilized by resonance that it can be represented by tautomeric forms [39].

\subsection{Tautomerism in Triazoles}

Tautomerism is possible in both the structural isomers of triazoles.

\subsubsection{Tautomerism in $1,2,3$-triazoles}

1,2,3-Triazoles have two tautomeric forms, $1 \mathrm{H}-1,2,3$-triazole (1) and 2H-1,2,3-triazole (2) [40].
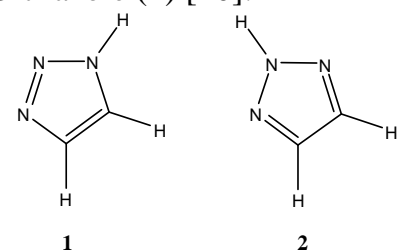

\subsubsection{Tautomerism in $1,2,4$-triazoles}

1, 2, 4-Triazoles have two tautomeric forms: $1 \mathrm{H}-1,2,4-$ triazole (3) and 4H-1,2,4-triazole (4) [41]. Many studies have been indicated that is tautomer (3) more sTable than tautomer (4) [42].

\subsubsection{Tautomerism in substituted-1,2,4-triazoles}

Among the substituted 1,2,4-triazoles, 3-mercapto-1, 2, 4triazoles exist in two tautomeric forms, that is mobile hydrogen can be attached either to the nitrogen (thion form) (5) or the sulfur (thiol form) (6). Thion (5) is the predominant form [42].<smiles>S=c1[nH]cn[nH]1</smiles>

5

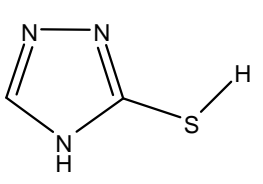

6
Other substituted 1, 2, 4-triazole can be exist in three tautomeric forms, such as:

1. Chloro-1,2,4-triazoles can exist as; 3-chloro-1H-1,2,4triazole (7a), 3-chloro-4H-1,2,4-triazole (7b) and 5-chloro$1 \mathrm{H}-1,2,4$-triazole $(7 \mathrm{c})$. Stability order of these tautomers is; $7 \mathrm{a}>7 \mathrm{c}>7 \mathrm{~b}$ according to physical and theoretical studies $[43,44]$.
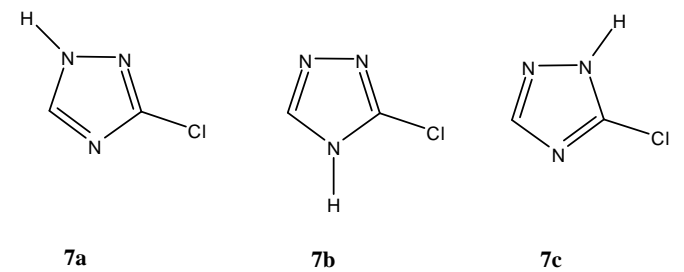

$7 c$
2. Bromo-1,2,4-triazoles, tautomeric forms of these compounds are, 3-bromo-1H-1,2,4-triazole (8a), 3-bromo$4 \mathrm{H}-1,2,4$-triazole (8b) and 5-bromo-1H-1,2,4-triazole (8c). According to the physical and theoretical studies [44], the tautomer (8a) and (8c) are of similar energy and the most stable tautomer is (8b).

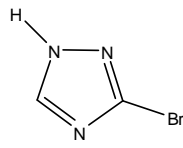

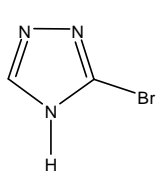

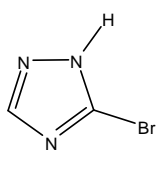

3. 3-Amino-1,2,4-triazole, can be exist as; 3-amino-1H-1,2,4triazole (9a), 3-amino-2H-1,2,4-triazole (9b) and 3-amino4H-1,2,4-triazole (9c). the stability order according to physical and theoretical studies [45] for the tautomers is; 9a $>9 \mathrm{~b}>9 \mathrm{c}$.
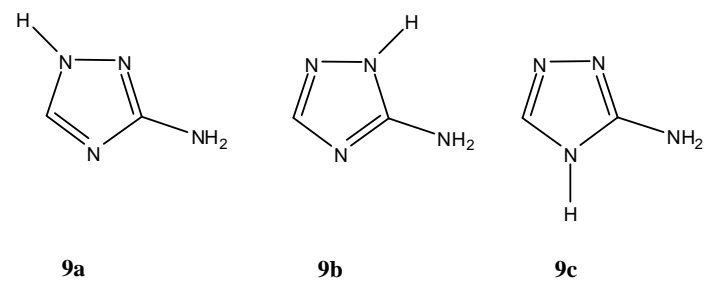

\section{Spectroscopy of 1,2,4-triazole}

Ultraviolet (UV), infrared (IR), nuclear magnetic resonance (NMR) and mass spectroscopic studies are very informative about the structure of 1, 2, 4-triazoles and their derivatives.

\subsection{Ultraviolet spectroscopy (UV)}

Holam and Straub, observed that in (UV) absorption spectrum, the un-substituted 1,2,4-triazole (5) shows a very weak absorption at $205 \mathrm{~nm}$. While in the case of N-acetyl1,2,4-triazole (10), Bathochromic shift occurs with the absorption band at $221.5 \mathrm{~nm}$. A similar shift in the maximum absorption of 3,5-dimethyl-1,2,4-triazole (11) appears in contrast with N-acetyl-3,5-dimethyl-1,2,4-triazole (12) [46].<smiles>CC(=O)n1cnnc1</smiles>

10

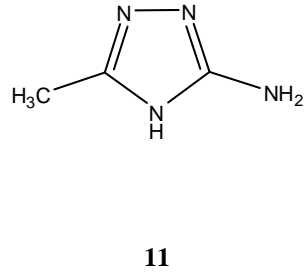

11<smiles>[R1]C(C)=O</smiles>

12
Thion-thiol tautomeric forms can also be detected by (UV) spectroscopy. That in case of 5-substituted-3-mercapto-1,2,4triazoles, the ultraviolet spectra of an ethanolic solution of these compounds usually show two maximum absorption bands at 252-256 $\mathrm{nm}$ and 288-298 $\mathrm{nm}$. The higher value of absorption is due to the presence of the chromophoric $\mathrm{C}=\mathrm{S}$ group [47]. 


\section{International Journal of Science and Research (IJSR) \\ ISSN (Online): 2319-7064}

Index Copernicus Value (2013): 6.14 | Impact Factor (2014): 5.611

\subsection{Infrared Spectroscopy (IR) [48]}

The infrared spectroscopy is very significant in characterization of triazole compounds. The absorption bands at $1570-1550 \mathrm{~cm}-1$ due to $\mathrm{N}=\mathrm{N}$ and in the region of $1600-1411 \mathrm{~cm}-1$ due to $\mathrm{C}=\mathrm{N}$ functions are the diagnostic features. In 5-substituted-4-amino-3-mercapto-1,2,4triazoles, thion-thiol tautomeric forms can also be identified in IR spectra by the presence of $\mathrm{C}=\mathrm{S}$ absorption band at about 1258-1166 cm-1 for thion and by characteristic SH absorption band at about 2700-2550 cm-1 for thiol forms. The primary $\mathrm{N}-\mathrm{H}$ stretching vibrations have been observed as two weak absorption bands near $3350 \mathrm{~cm}-1$ and $3250 \mathrm{~cm}-$ 1 have also been found supportive of thion-thiol equilibrium. Also, the appearance of $\mathrm{N}-\mathrm{H}$ bands in the regions of 3200 $3100 \mathrm{~cm}-1$.

\subsection{Nuclear Magnetic Resonance (NMR)}

Both $1 \mathrm{H}$ and 13C NMR are important to verify the structure of the derivatives, also they are useful in synthesis of isomers. Important 13C NMR and 1H NMR chemical shifts can be shown in Table (1-2), and number of atoms can be shown in (Fig. 1) [49].

Table 2: Theoretical and experimental ${ }^{1} \mathrm{H}$ and ${ }^{13} \mathrm{C}$ isotropic chemical shifts (all values in ppm) for the 4-Amino-3-phenyl1H-1,2,4-triazole-5(4H)-thione [49]

\begin{tabular}{|c|c|c|}
\hline Atom & Experimental $(\mathrm{ppm})$ & Calculated $(\mathrm{ppm})$ \\
\hline C1 & 128.57 & 121.59 \\
\hline C2 & 130.98 & 122.48 \\
\hline C3 & 129.03 & 124.31 \\
\hline C4 & 126.27 & 125.08 \\
\hline C5 & 129.03 & 124.31 \\
\hline C6 & 130.98 & 122.48 \\
\hline C7 & 150.02 & 146.66 \\
\hline C9 & 167.39 & 154.48 \\
\hline H14 & 7.99 & 6.86 \\
\hline H15 & 7.52 & 6.75 \\
\hline H16 & 7.48 & 6.07 \\
\hline H17 & 7.51 & 6.98 \\
\hline H18 & 8.03 & 8.92 \\
\hline H19 & 13.99 & 11.86 \\
\hline H20 & 5.78 & 5.15 \\
\hline H21 & 5.78 & 5.06 \\
\hline
\end{tabular}

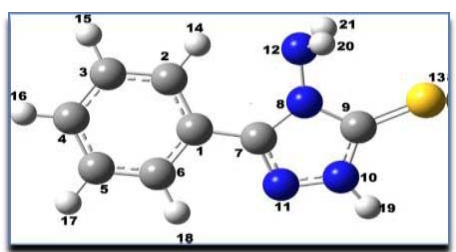

Figure 2: Molecular structure of 4-amino-3-phenyl- $1 \mathrm{H}$ 1,2,4-triazole- $(4 \mathrm{H})$-thione along with numbering of atom [49]

13C NMR is a powerful tool to characterize thion and thiol tautomers. In the spectrum of thion two values for chemical shifts are obtained, one at about $164-173 \mathrm{ppm}$ for imine $(\mathrm{C}=\mathrm{N})$ and the other at $150-160 \mathrm{ppm}$ for thionyl $(\mathrm{C}=\mathrm{S})$. While in thiol tautomer there is chemical shift in 50-75 ppm for (C-S) instead of thionyl group [48].

\subsection{Mass Spectrometry (MS) [50]}

1,2,4-Triazoles have a strong molecular ion peak with the cleavage of bonds between $\mathrm{N} 1-\mathrm{N} 2$ and $\mathrm{N} 4-\mathrm{C} 5$ has been observed. In addition of $\mathrm{N} 1-\mathrm{N} 2$ and $\mathrm{C} 3-\mathrm{N} 4$ cleavage, number of atoms can be shown in (Fig. 1-2).

\section{Synthetic Methods of 1,2,4-Triazoles}

\subsection{From Carboxylic Acid Hydrazide}

N-(3-mercapto-5-phenyl-4H-1,2,4-triazol-4-yl) hydrazine carbothioamide (VI) prepared from the condensation of 4amino-5-phenyl-4H-1,2,4-triazole-3-thiol and thiosemicarbazide (III) which synthesized by reaction of hydrazine hydrate and 5-phenyl-1,3,4-oxadiazol-2-ylamine (II), which in itself was synthesized from benzoic acid hydrazide (I) [51], As shown in Scheme (1).

While 6-(substituted)-3-(pyridin-4-yl)-1,2,4-triazole [3,4-b] $[1,3,4]$ thiadiazole (IV) has the synthetic root of isonicotinic acid hydrazide (I) which has been converted to potassium dithiocarbazinate (II). Then, salt (II) has been treated with hydrazine hydrate to yield 1,2,4-triazole (III), which treated with various carboxylic acids to get a series of compound (IV a-j) [52], as shown in Scheme (2).

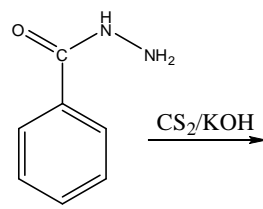

I

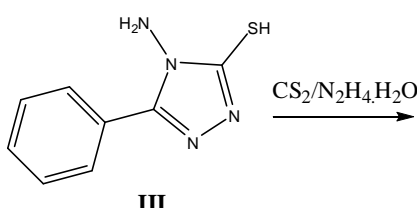

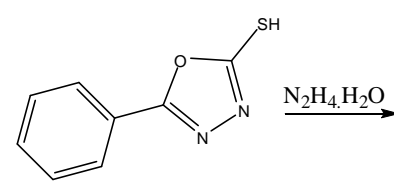

II

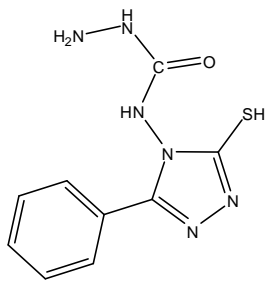

VI
Scheme (1): Synthesis of N-(3-mercapto-5-phenyl-4H-1,2,4triazol-4-yl) hydrazinecarbothioamide

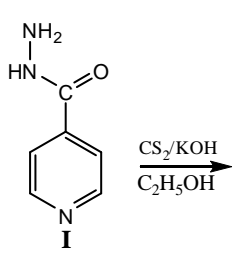

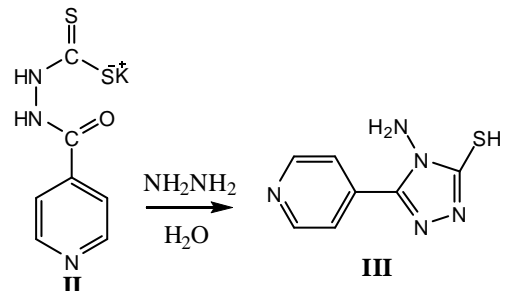
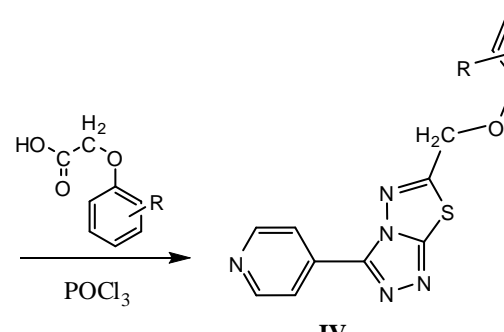

IV

Scheme (2): Synthesis of 6-(substituted)-3-(pyridin-4-yl)1,2,4-triazole[3,4-b][1,3,4]thiadiazole

\section{Volume 5 Issue 3, March 2016}


<smiles>Nc1ncnc(O)n1</smiles>

$\downarrow$<smiles>Nc1ncnc2nnc(S)n12</smiles><smiles>O=Cc1ccc([N+](=O)[O-])cc1</smiles><smiles>Nc1ncnc2nnc(-c3ccc([N+](=O)[O-])cc3)n12</smiles>

IV

\subsection{From Thiosemicarbazide}

5-(4-Nitrophenyl)-4-phenyl-4H-1,2,4-triazole-3-thiol were prepared from 1-phenyl-4-(4nitrobenzoyl)thiosemicarbazide (I) [55], As shown in Scheme (5).

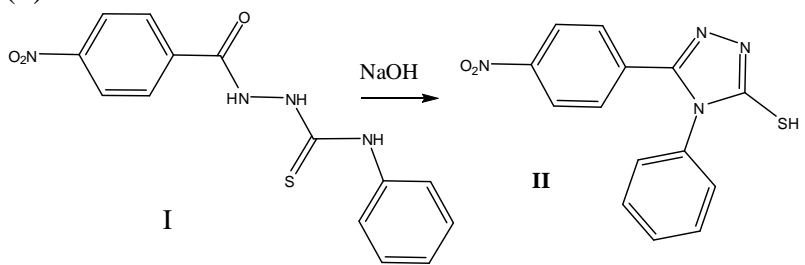

Scheme (5): Synthesis of 5-(4-Nitrophenyl)-4-phenyl-4H1,2,4-triazole-3-thiol

\subsection{From Urea}

Reaction of 3-benzylidene phthalide (I) with urea under microwave irradiation (MWI) gave 1-(2- $(\alpha-$ phenylacetyl)benzoyl)urea (II) which reacted with hydrazine hydrate to yield 1-(2-(5-amino-4H-1,2,4-triazol-3-yl)phenyl)2-phenylethanone (III) [56], As shown in Scheme (6).

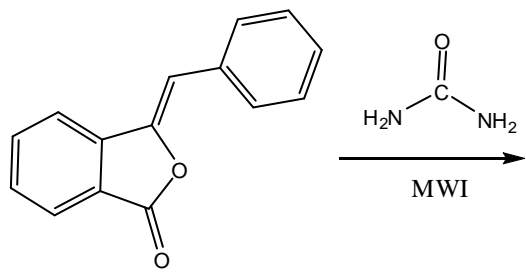
triazine (III), 5-amino[1,2,4]triazolo[4,3-a][1,3,5]triazine-3thiol (IV), and 5-amino-3-phenyl[1,2,4]triazolo[4,3a][1,3,5]triazine (V) were synthesized from 2-amino-4hydrazino-1,3,5-triazine (II) which has been prepared by substitution of hydroxy group in 2-Amino-4-hydroxy-1,3,5triazine (II) with hydrazino group [53], as shown in Scheme (3).

\subsection{From Oxazole}

After the substitution of mecapto group in 2-meracpto benzoxazole (I) with hydrazino group to prepare 2hydrazino benzoxazol (II), Reaction of (II) with carbon disulfide and sodium hydroxide gave 1,2,4-triazole [4,3-b] benzoxazole-1-(2H)thione (III) [54], As shown in Scheme (4).<smiles>Nc1nc2ccccc2o1</smiles><smiles>FS(F)(F)(F)(F)c1ccc2oc3nnc(S)n3c2c1</smiles>

III<smiles>NNc1nc2ccccc2o1</smiles>

II<smiles>NC(=O)NC(=O)c1ccccc1C(=O)Cc1ccccc1</smiles>

II<smiles></smiles>

III

Scheme (6): Synthesis of 1-(2-(5-amino-4H-1,2,4-triazol-3yl)phenyl)-2-phenylethanone

\subsection{From Acid Chloride}

Conventional heating of 3-chloro-2chlorocarbonylbenzo[b]thiophene (I) with hydrazine hydrate afforded the corresponding hydrazide (II). Potassium dithiocarbazate (III) was cyclized with hydrazine to afford 4amino-5-(3-chlorobenzo [b] thien-2-yl)-3-mercapto-1,2,4triazole (IV) [57], As shown in Scheme (7).

Scheme (4): Synthesis of 1,2,4-triazole [4,3-b] benzoxazole1-(2H)thione 
<smiles>C[C@H](N)c1ccc2sc(C(N)=O)c(Cl)c2c1</smiles>

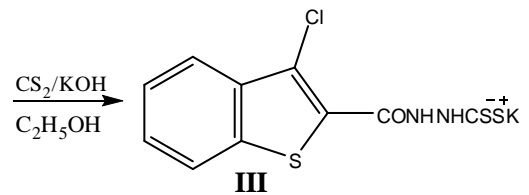<smiles>N#C[C@@H](O)C(=O)O</smiles>

Scheme (7): Synthesis of 4-amino-5-(3-chlorobenzo[b]thien2-yl)-3-mercapto-1,2,4-triazole

\section{Applications and Biological Activities}

1,2,4-Triazole and its derivatives are an imperative type of compounds which possess environmental [58], industrial [11, 17, 59], agricultural [62, 67, 69] and biological activities, including antimicrobial [60-64], antifungal [65], antibacterial [66-68], antitubercular [69], anticancer [70-72], anti-oxidant [67, 69, 73], anti-inflammatory [74, 75], antiviral [16, 76], and anticonvulsant [77] activities.

\subsection{Agricultural Applications}

Azole derivatives have been used in the plant protection technology as pesticides [77]. In order to selectively control the growth of weeds, a wide range of azole herbicides have been developed that are exhibiting [78]:

- high level of activity

- application flexibility

- crop tolerance

- low levels of toxicity to mammals

Specifically, triazoles play an important role among this classes of heterocyclic compounds [50, 51].

Sutton et al. [44] have been evaluated a good in vitro activity of Etaconazole on fungi that causing summer disease of apple. While Amer et al. [49] have been determined diniconazole fungicides residues in tomatoes and green beans by capillary gas chromatography.

Schermerhorn et al. [79] have been determined 22 triazole compounds including parents fungicides and metabolites in apple, peaches, flour and water by liquid chromatography/tandem mass spectroscopy, and the most three common fungicides triazole are: 1,2,4-triazole (2), triazolyalanine (13), and triazolylacetic acid (14).<smiles>Cc1ncn(CC(N)C(=O)O)n1</smiles><smiles>O=C(O)Cn1cncn1</smiles>

14

\subsection{Pharmacological Applications}

Over the last few decades, the biological and pharmaceutical properties of 1,2,4-triazoles have been formed considerable attention in their synthesis and characterization [80]. 1,2,4Triazole and its derivatives possess widely different biological activities Figure (3).

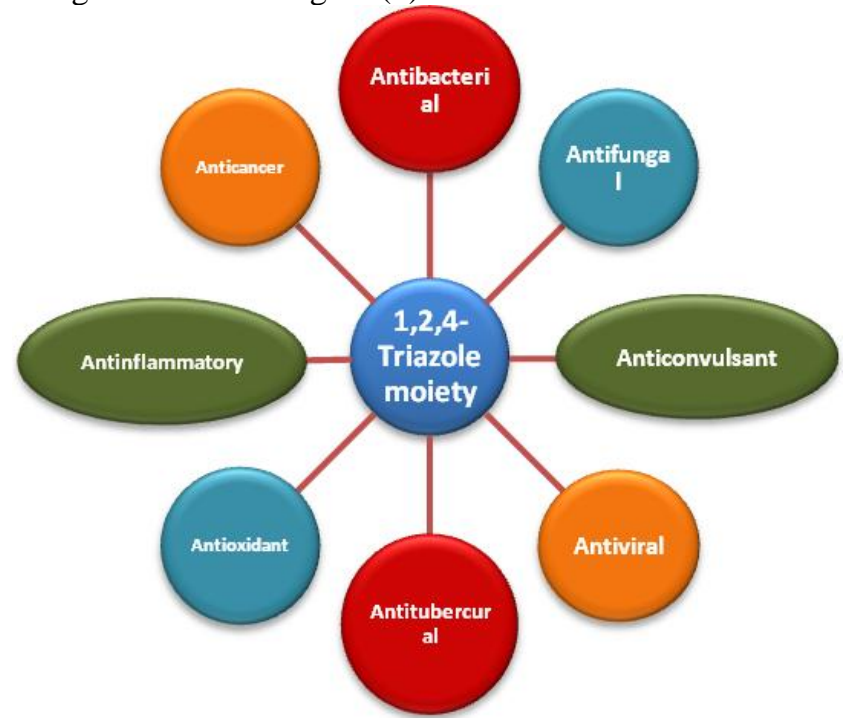

Figure 3: Pharmacological activities of triazole moiety

\subsubsection{Antibacterial Activities}

Battle against bacterial infections has resulted in the development of a wide variety of antibiotics. After years of mistreatment and overuse of antibiotics, bacteria are becoming antibiotic resistant, resulting in a potential global health disaster. It is recommended to use new antibacterial agents with enhanced broad spectrum potency. Therefore, recent efforts have been directed toward exploring novel antibacterial agents. Antibacterial drug is a chemical substance derivable from a mold or bacterium that can kill microorganisms and cure bacterial infections, Many antibiotics are now chemically modified from original compounds present naturally. They are classified in two types based on their mode of action as bactericidal agents (kill bacteria directly) and bacteriostatic agent (stop bacteria from growing) [81]. Uchil et al. [82] have been synthesized and used (substituted- $(+) \alpha-(4$-chlorophenyl)- $\beta$ (phenylmethylene)-1H-1,2,4-triazole-1-ethanols) [15] as bacteriostatic agent. 


\section{International Journal of Science and Research (IJSR) \\ ISSN (Online): 2319-7064}

Index Copernicus Value (2013): 6.14 | Impact Factor (2014): 5.611

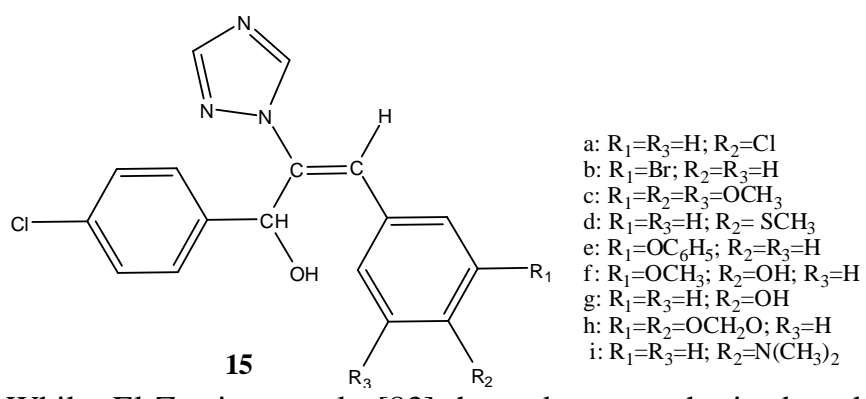

While El-Zemity et al. [83] have been synthesized and evaluated the Bactericidal Potential of (1H-1,2,4-triazol-1-yl methyl)Phenols (16), N,N-dialkyl Anilines (17), and N-alkyl Anilines (18).

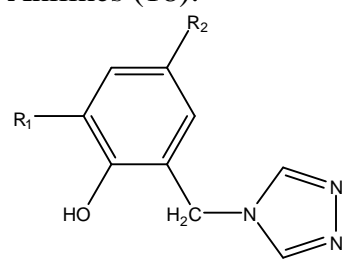

a: $\mathrm{R}_{1}=\mathrm{R}_{2}=\mathrm{H}$

b: $\mathrm{R}_{1}=\mathrm{CH}_{3} ; \mathrm{R}_{2}=\mathrm{H}$

c: $\mathrm{R}_{1}=\mathrm{H} ; \mathrm{R}_{2}=\mathrm{CH}_{3}$

d: $\mathrm{R}_{1}=\mathrm{i}-\mathrm{C}_{4} \mathrm{H}_{9} ; \mathrm{R}_{2}=\mathrm{H}$

e: $\mathrm{R}_{1}=\mathrm{t}-\mathrm{C}_{4} \mathrm{H}_{9} ; \mathrm{R}_{2}=\mathrm{CH}$

$\mathrm{f}: \mathrm{R}_{1}=\mathrm{s}-\mathrm{C}_{4} \mathrm{H}_{9} ; \mathrm{R}_{2}=\mathrm{CH}_{3}$

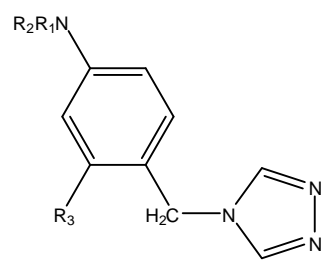

a: $\mathrm{R}_{1}=\mathrm{R}_{2}=\mathrm{R}_{3}=\mathrm{H}$

b: $\mathrm{R}_{1}=\mathrm{CH}_{3} ; \mathrm{R}_{2}=\mathrm{R}_{3}=\mathrm{H}$

c: $\mathrm{R}_{1}=\mathrm{C}_{2} \mathrm{H}_{5} ; \mathrm{R}_{2}=\mathrm{R}_{3}=\mathrm{H}$

d: $\mathrm{R}_{1}=\mathrm{C}_{2} \mathrm{H}_{5} ; \mathrm{R}_{2}=\mathrm{H} ; \mathrm{R}_{3}=\mathrm{CH}_{3}$

e: $\mathrm{CH}_{3} \mathrm{CH}_{3} \mathrm{H}$

$\mathrm{f}: \mathrm{R}_{1}=\mathrm{R}_{2}=\mathrm{R}_{3}=\mathrm{CH}_{3}$

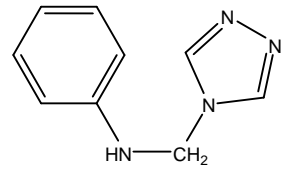

18

Narayana Rao et al. [80], have been synthesized and characterized a new 1,2,4-triazole derivatives. Also, they have been evaluated the biological activity 4-[(3-(4substituted-phenoxymethyl)-5-benzylsulfonyl)-1,2,4-triazol4-yl) methyl]-morpholine (19) and All the title compounds showed good antibacterial and antifungal activities.

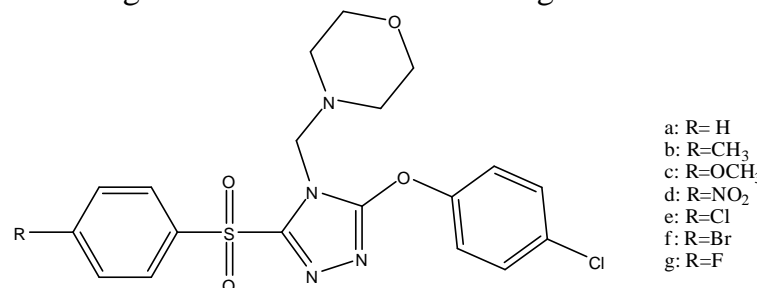

\subsubsection{Antifungal Activities}

Antifungal are the class of drugs that are used to eliminate fungal infections from the human body. They work by exploiting differences between mammalian and fungal cells to eliminate fungal organism without harming the host cells. As both the cells are eukaryotic in nature so it is more difficult to design the drugs of antifungal activity with fine selections of the cells without causing any side effects [84].

The mechanism of action of triazole antifungal, was investigated with Trichophyton mentagrophytes and Candida albicans by Tatsumi et al. whom explained that Efinaconazole (20) dose-dependently decreased ergosterol production and accumulated 4,4-dimethylsterols and $4 \alpha-$ methylsterols. Efinaconazole induced morphological and ultrastructural changes in $\mathrm{T}$. mentagrophytes hyphae that became more prominent with increasing drug concentrations. In conclusion, the primary mechanism of action of efinaconazole is blockage of ergosterol biosynthesis, presumably through sterol $14 \alpha$-demethylase inhibition, leading to secondary degenerative changes [85].<smiles>C=C1CCN([C@@H](C)[C@](O)(Cn2cncn2)c2ccc(F)cc2F)CC1</smiles>

Anti (Mucor, Aspergillus Niger and Penicillium) were synthesized and characterized by Patel et al. whom prepared 3-(Substitutedphenyl)-N-(4H-1,2,4-triazol-4-yl) acrylamide derivatives (21) [86].

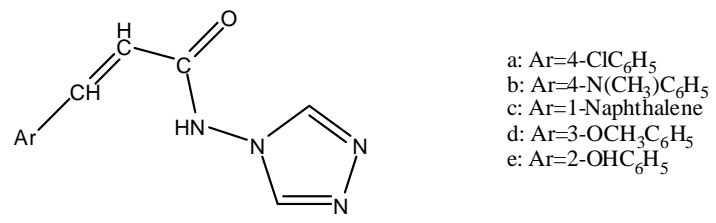

21

Suresh et al. found that (Z)-2-(4-substitutedbenzylidene)-7isocyano-3,6- dioxo-8-phenyl-3,6-dihydro-2H-thiazolo[3',2':2,3][1,2,4]-triazolo[1,5-a]pyridine-9-carbon nitrile derivatives (22) exhibit good antifungal activity against Aspergillus flavus, Aspergillus fumigatus, Candida albicans, Penicillium marneffei and Trichophyton mentagrophytes [87].<smiles></smiles>

\subsubsection{Anticancer and Antitumor Activities}

Cancer, a diverse group of diseases identified by the production and prevalence of abnormal cells, is a major global problem [88]. Therefore, the discovery and development of new effective and selective anticancer drugs are of high importance in modern cancer researches. 1,2,4Triazole derivatives have their chance with these researches with a good results [41, 59]. Li et al., synthesized and evaluated in vitro anticancer activity of 12 hybrid 1,2,4triazole Schiff's bases (23) bearing $\gamma$-substituted butenolide moiety [89]. 


\section{International Journal of Science and Research (IJSR) \\ ISSN (Online): 2319-7064 \\ Index Copernicus Value (2013): 6.14 | Impact Factor (2014): 5.611}

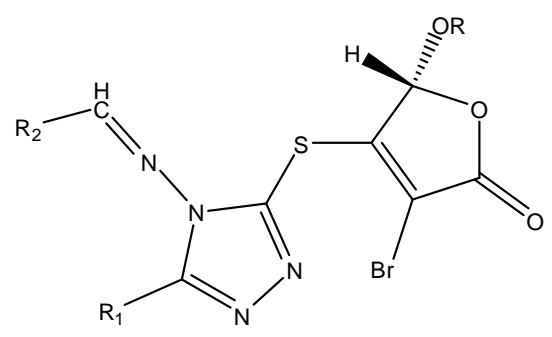

23

a: R=1-menthyl; $\mathrm{R}_{1}=\mathrm{C}_{6} \mathrm{H}_{5}, \mathrm{R}_{2}=4-\mathrm{Cl}-\mathrm{C}_{6} \mathrm{H}_{5}$

b: $\mathrm{R}=1$-menthyl; $\mathrm{R}_{1}=4-\mathrm{CH}_{3} \mathrm{O}-\mathrm{C}_{6} \mathrm{H}_{5} ; \mathrm{R}_{2}=4-\mathrm{Cl}-\mathrm{C}_{6} \mathrm{H}_{5}$

c: $\mathrm{R}=1$-menthyl; $\mathrm{R}_{1}=\mathrm{C}_{6} \mathrm{H}_{5} ; \mathrm{R}_{2}=4-\mathrm{O}_{2} \mathrm{~N}-\mathrm{C}_{6} \mathrm{H}_{5}$

d: $\mathrm{R}=1$-menthyl; $\mathrm{R}_{1}=4-\mathrm{CH}_{3} \mathrm{O}-\mathrm{C}_{6} \mathrm{H}_{5} ; \mathrm{R}_{2}=4-\mathrm{O}_{2} \mathrm{~N}-\mathrm{C}_{6} \mathrm{H}_{5}$

e: $\mathrm{R}=1$-menthyl; $\mathrm{R}_{1}=\mathrm{C}_{6} \mathrm{H}_{5} ; \mathrm{R}_{2}=2$-furanl

f: $\mathrm{R}=1$-menthyl; $\mathrm{R}_{1}=4-\mathrm{CH}_{3} \mathrm{O}-\mathrm{C}_{6} \mathrm{H}_{5} ; \mathrm{R}_{2}=2$-furanl

g: $\mathrm{R}=1$-menthyl; $\mathrm{R}_{1}=\mathrm{CH}_{3} ; \mathrm{R}_{2}=4-\mathrm{Cl}_{-} \mathrm{C}_{6} \mathrm{H}_{5}$

h: R=1-menthyl; $\mathrm{R}_{1}=4-\mathrm{HO}-\mathrm{C}_{6} \mathrm{H}_{5} ; \mathrm{R}_{2}=4-\mathrm{CH}_{3} \mathrm{O}-\mathrm{C}_{6} \mathrm{H}_{5}$

i: $\mathrm{R}=1$-menthyl; $\mathrm{R}_{1}=\mathrm{C}_{6} \mathrm{H}_{5} ; \mathrm{R}_{2}=4-\mathrm{HO}-\mathrm{C}_{6} \mathrm{H}_{5}$

$\mathrm{j}: \mathrm{R}=$ bornyl; $\mathrm{R}_{1}=\mathrm{C}_{6} \mathrm{H}_{5} ; \mathrm{R}_{2}=4-\mathrm{Cl}-\mathrm{C}_{6} \mathrm{H}_{5}$

$\mathrm{k}: \mathrm{R}=$ bornyl; $\mathrm{R}_{1}=4-\mathrm{HO}-\mathrm{C}_{6} \mathrm{H}_{5} ; \mathrm{R}_{2}=4-\mathrm{CH}_{3} \mathrm{O}-\mathrm{C}_{6} \mathrm{H}_{5}$

l: $\mathrm{R}=$ bornyl; $\mathrm{R}_{1}=\mathrm{CH}_{3} ; \mathrm{R}_{2}=2-\mathrm{HO}-\mathrm{C}_{6} \mathrm{H}_{5}$

A. Anton Smith et al. have been synthesized and evaluated in vitro anticancer activity of 1,2,4-triazole derivatives (24) [72].<smiles>[R3]Cn1nc(-c2ccc(O)cc2)n(/N=C/c2ccc([R2])cc2[R1])c1=S</smiles>

24

a: $\mathrm{R}_{1}=\mathrm{R}_{2}=\mathrm{Cl} ; \mathrm{R}_{3}=\mathrm{N}\left(\mathrm{C}_{2} \mathrm{H}_{5}\right)_{2}$

b: $\mathrm{R}_{1}=\mathrm{H} ; \mathrm{R}_{2}=\mathrm{NO}_{2} ; \mathrm{R}_{3}=\mathrm{N}\left(\mathrm{C}_{2} \mathrm{H}_{5}\right)_{2}$

c: $\mathrm{R}_{1}=\mathrm{H} ; \mathrm{R}_{2}=\mathrm{N}\left(\mathrm{CH}_{3}\right)_{2} ; \mathrm{R}_{3}=\mathrm{N}\left(\mathrm{C}_{2} \mathrm{H}_{5}\right)_{2}$

d: $\mathrm{R}_{1}=\mathrm{R}_{2}=\mathrm{Cl} ; \mathrm{R}_{3}=\mathrm{N}$-pyridyl

e: $\mathrm{R}_{1}=\mathrm{H} ; \mathrm{R}_{2}=\mathrm{NO}_{2} ; \mathrm{R}_{3}=\mathrm{N}$-pyridyl

f: $\mathrm{R}_{1}=\mathrm{H} ; \mathrm{R}_{2}=\mathrm{N}\left(\mathrm{CH}_{3}\right)_{2} ; \mathrm{R}_{3}=\mathrm{N}$-pyridyl

g: $\mathrm{R}_{1}=\mathrm{R}_{2}=\mathrm{Cl} ; \mathrm{R}_{3}=\mathrm{N}$-morpholinyl

h: $\mathrm{R}_{1}=\mathrm{H} ; \mathrm{R}_{2}=\mathrm{NO}_{2} ; \mathrm{R}_{3}=\mathrm{N}$-morpholinyl

i: $\mathrm{R}_{1}=\mathrm{H} ; \mathrm{R}_{2}=\mathrm{N}\left(\mathrm{CH}_{3}\right)_{2} ; \mathrm{R}_{3}=\mathrm{N}$-morpholinyl

Y.-P. Hou et al. have been synthesized 1,2,4-triazole derivatives (25) that have antitumor activity with 1,4benzodioxane fragment as a novel class potent methionine aminopeptidase type II inhibitors [70].

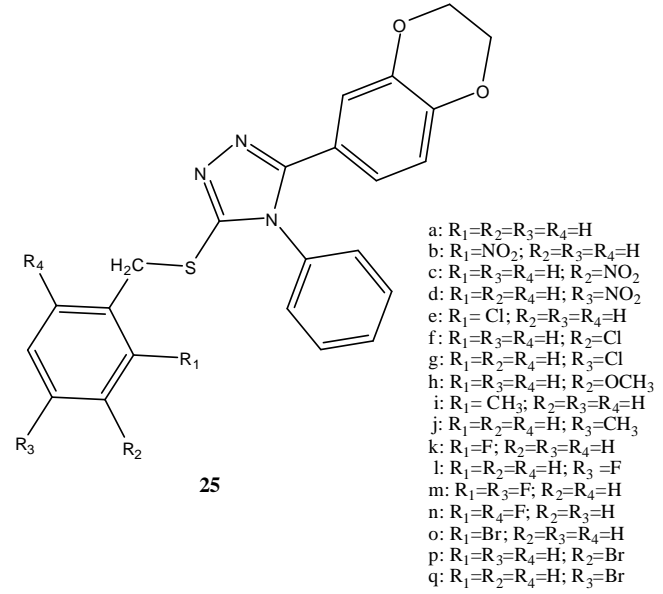

B. A. Baviskar et al. have been synthesized clubbed triazolyl indeno [1,2-C]isoquinolines (26) as anticancer agent [71].<smiles></smiles>

\subsubsection{Anti-inflammatory Activities}

Therapeutic use of non-steroidal anti-inflammatory drugs (NSAIDs) which are used in treatment of a number of arthritic diseases is limited because of their side effects, such as, gastrointestinal haemorrhage and ulceration. So, new drugs having effective anti-inflammatory activity with minimum side effects have been developed [75].

A series of hybrids from diaryl-1,2,4-triazole and $\mathrm{N}$ hydroxyurea (27) were synthesized, evaluated as novel antiinflammatory agents, and displayed promising analgesic activity in acetic acid-induced writhing response and hotplate assay, by Jiang et al. [90].<smiles>CC(O)(O)c1ccc(-c2nc(SCCN(O)C(N)=O)nn2-c2ccc(Br)cc2)cc1</smiles>

27

Subbarao et al. have been evaluated a good antiinflammatory activities of novel series of 1,2,4-triazolo [ 3,4b] [ 1,3,4 ] thiadiazoles (28) [91].<smiles>[R]C1C(c2nn3c(C(C)c4ccc(C(C)C(C)C)cc4)nnc3s2)=C(N)Cc2cc3ccccc3cc21</smiles>

28

Murti et al. have been characterized the anti-inflammatory activity of 4-(Substituted benzylideneamino)-5-(pyridin-4yl)-4H-1,2,4-triazol-3-thiol derivatives (29) [92]. 


\section{International Journal of Science and Research (IJSR) \\ ISSN (Online): 2319-7064}

Index Copernicus Value (2013): 6.14 | Impact Factor (2014): 5.611<smiles>[R]Cc1cccc(/C=N/n2c(S)nnc2-c2ccncc2)c1</smiles>

29

$\mathrm{R}=4-\mathrm{Cl}, 3-\mathrm{OH}, 4-\mathrm{OCH}_{3}, 2-\mathrm{NO}_{2}, 4-\mathrm{N}\left(\mathrm{CH}_{3}\right)_{2}$

\subsubsection{Anticonvulsant Activities}

Anticonvulsants are drugs that avoid or decrease the severity and rate of seizures in various types of epilepsy. The different types of anticonvulsants may proceed on different receptors in the brain and have different forms of action [93]. 1,2,4-triazole derivatives considered as a good anticonvulsants such as alprazoam (39).

Wingrove et al. put forward a hypothesis that the activity of loreclezole (30) (second-generation antiepileptic drug) is dependent on the interaction between the triazole moiety and the amide group of asparagine (Asn-289), which is located on the $\beta 2$ subunit of the GABAA receptor [94].<smiles>Cl/C(=C\n1cncn1)c1ccc(Cl)cc1Cl</smiles>

30

Plech et al. have been Studied on the anticonvulsant activity and influence on GABA-ergic neurotransmission of 1,2,4triazole-3-thione based compounds (31), (32), and (33) [95].

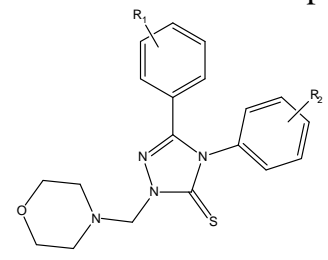

a. $\mathrm{R}_{1}=3-\mathrm{Cl}, \mathrm{R}_{2}=4-\mathrm{B} \mathrm{r}$ b. $\mathrm{R}_{1}=3-\mathrm{Cl}, \mathrm{R}_{2}=4-\mathrm{C} \mathrm{H}_{3}$ c , $\mathrm{R}_{1}=4-\mathrm{Cl}, \mathrm{R}_{2}=2-\mathrm{B} \mathrm{r}$

d. $\mathrm{R}_{1}=4-\mathrm{Cl}, \mathrm{R}_{2}=4-\mathrm{B} \mathrm{r}$

31

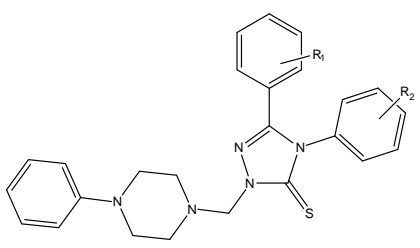

a, $\mathrm{R}_{1}=3-\mathrm{Cl}, \mathrm{R}_{2}=4-\mathrm{Br}$

b. $\mathrm{R}_{1}=3-\mathrm{Cl}, \mathrm{R}_{2}=4-\mathrm{CH}_{3}$

c , $\mathrm{R}_{1}=4-\mathrm{Cl}, \mathrm{R}_{2}=2-\mathrm{Br}$

d. $\mathrm{R}_{1}=4-\mathrm{Cl}, \mathrm{R}_{2}=4-\mathrm{Br}$

32

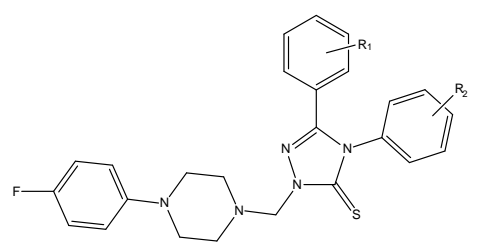

a . $\mathrm{R}_{1}=3-\mathrm{Cl}, \mathrm{R}_{2}=4-\mathrm{Br}$

b. $\mathrm{R}_{1}=3-\mathrm{Cl}, \mathrm{R}_{2}=4-\mathrm{CH}_{3}$

c. $\mathrm{R}_{1}=4-\mathrm{Cl}, \mathrm{R}_{2}=2-\mathrm{Br}$

d. $\mathrm{R}_{1}=4-\mathrm{Cl}, \mathrm{R}_{2}=4-\mathrm{Br}$
D. Kumudha et al. synthesized and evaluated anticonvulsant and CNS depressant activity of some 1,3,4-thiadiazoles having substituted 1,2,4-triazole moiety (34) [96].

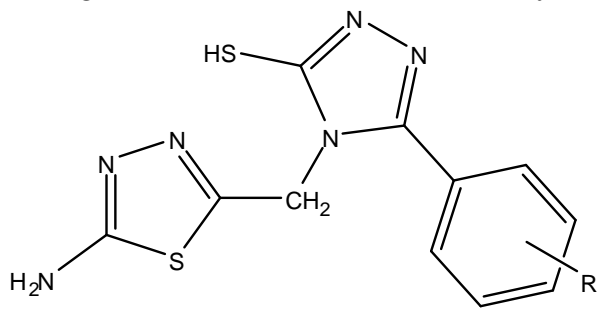

34

$$
\mathrm{R}=\mathrm{H} ; 2-\mathrm{Cl} ; 3-\mathrm{CH}_{3} ; 4-\mathrm{CH}_{3}
$$

\subsubsection{Antiviral Activities}

Antiviral drugs are a class of medication used specifically for treating viral infections. specific antivirals are used for specific viruses [97].

K. Benci et al. were synthesized and evaluated 1,2,4-triazole acyclic cyclopropane nucleoside analogues (35) [98].

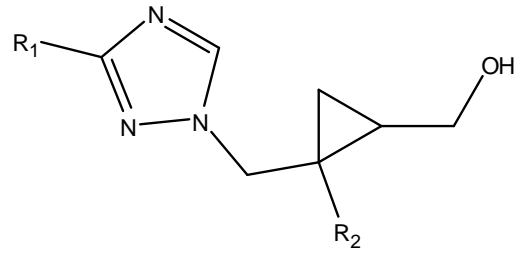

35

a: $\mathrm{R}_{1}=\mathrm{H}, \mathrm{R}_{2}=\mathrm{CH}_{2} \mathrm{OH}$

b: $\mathrm{R}_{1}=\mathrm{CH}_{2} \mathrm{OH}, \mathrm{R}_{2}=\mathrm{CH}_{2} \mathrm{OH}$

c: $\mathrm{R}_{1}=\mathrm{CONH}_{2}, \mathrm{R}_{2}=\mathrm{CH}_{2} \mathrm{OH}$

d: $\mathrm{R}_{1}=\mathrm{CONH}_{2}, \mathrm{R}_{2}=\mathrm{CONH}_{2}$

A. Abou-zeid et al. were used 1,2,4-traizole derivatives (36) and (37) as antiviral agents [99].

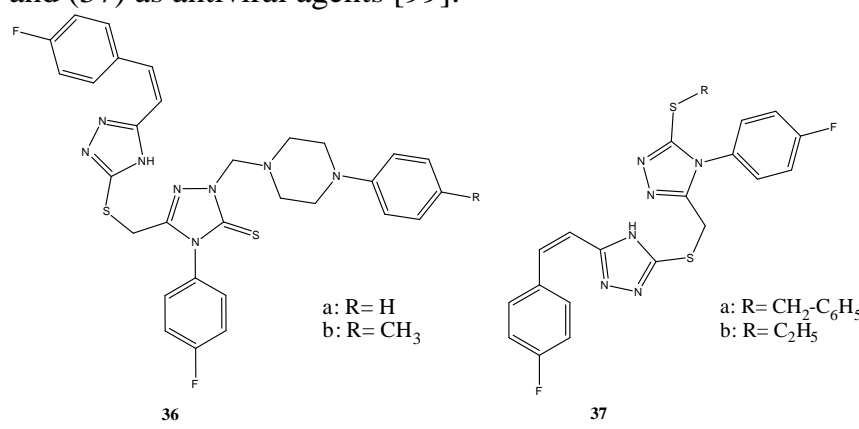

\subsubsection{Antitubercular Activities}

Tuberculosis is still a major treat to mankind. The increasing problem of Multi-Drug Resistant-tuberculosis has focused attention on developing new drugs that are not only active against drug resistant tuberculosis, but also shorten the lengthy therapy. There is urgent need and significant interest in developing new tubercular drugs. In developing new tubercular drugs, it is essential to think about which targets in the tubercule bacillus are good drug targets. Several recent reviews on this topic are already available [96, 100, and 101].

M. Maste Meenaxi et al. were studied the antitubercular activity of 1,2,4-triazole derivatives (38) [69]. 


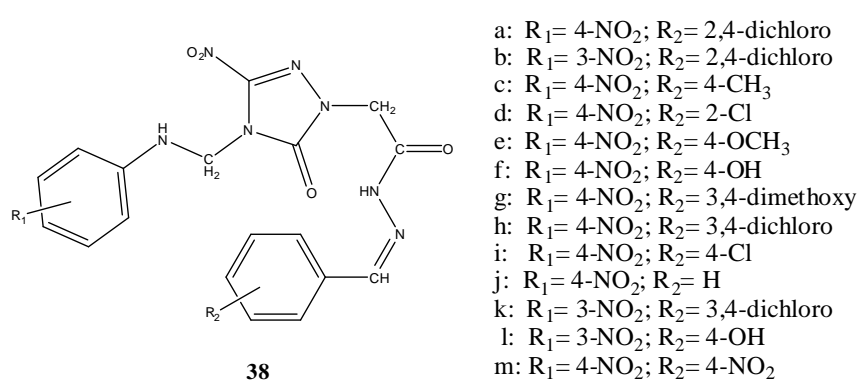

6.2.8. Antioxidant Activities

Damage to cells caused by free radical is supposed to play an essential role in the aging process and in disease development. antioxidants are our first line of protection against free radical damage, The antioxidants became even more critical with amplified exposure to free radicals. pollution, cigarette smoke, drugs, illness, stress and even exercise can increase free radical exposure [102].

A. Abdul Hameed and F. Hassan have been synthesized and evaluated antioxidant activity of 4-amino-5-phenyl-4H-1,2,4triazole-3-thiol derivatives (39) [73]. K. Sancak et al. found that tri-substituted triazole (40) and (41) possess highly potent antioxidant properties [103].<smiles>[R]c1ccc(C2SCC(=O)N2n2c(S)nnc2-c2ccccc2)cc1</smiles>

39

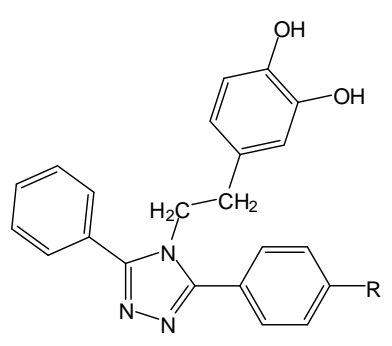

40

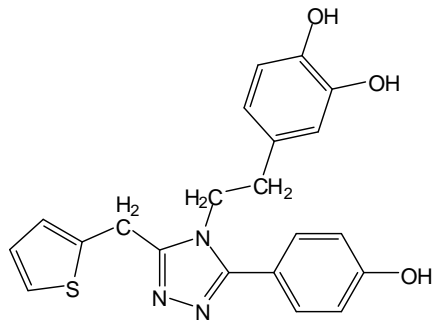

41<smiles>O=C(Nc1nn2c(S)nnc2s1)c1ccc([N+](=O)[O-])cc1[N+](=O)[O-]</smiles>

Also, triazole have been used as acid-base indicator because it shows reversible, clear colour change, sharp and low relative error ( $\mathrm{RE} \mathrm{1.4 \% )} \mathrm{in} \mathrm{the} \mathrm{pH}$ range 8.5-10.1, As shown in Scheme (8) (20).
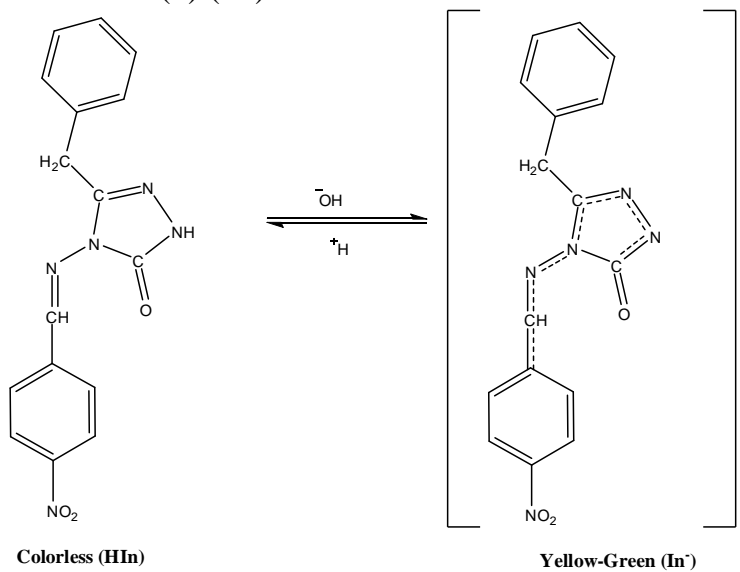

Scheme (8): Resonance structures of 3-benzyl-4-pnitrobenzylidenamino - 4,5-dihydro-1,2,4-triazole-5-one, Whereas In = indicator

Some triazole systems have extensive use in the separation of silver from other metal cations in liquid membrane systems [105]. In addition, these compounds are used as synthetic dyes and bleaching agents [106], It also they are used as nonionic surfactants [107]. Moreover, triazoles (43) have also been reported as inhibitors of corrosion of aluminum in hydrochloric acid solution [17].<smiles>Nc1nnc(-c2ccccc2)[nH]1</smiles>

43

\section{References}

[1] A. Kamal., MA. Syed, \& SM. Mohammed. "Theraputic Potential of Benzothaizole," A Patent Review (20102104). Informa healthcare, 25 (3), 335-349, 2015.

[2] A. Bretschnider, E. Franken, U. Görgens, M. Füsslein, A. Hense, J. Kluth, HG. Schwarz, A. Kohler, O. Malsam, A. Voerste, \& A. Becker, Heterosyclic Compounds as Pestisides. United states: Patent Application Publisher, 2014.

[3] P. Gourdon, JH. Andersen, KL. Hein, M. Bublitz, BP. Bendersen, X. Liu, L. Yatime, M. Nyblom, TT. Nielsen, C. Olsen, JV. Møller, P. Nissem, \& JP. Morth, "HiLiDe-Systematic Approach to Membrane Protein Crystallization in Lipid and Detergent. Cryst," Growth Des., 11 (6), 2098-2106, 2011. 


\section{International Journal of Science and Research (IJSR) \\ ISSN (Online): 2319-7064}

Index Copernicus Value (2013): 6.14 | Impact Factor (2014): 5.611

[4] P. Yang, PA. Martos, \& B. Barrett, "Symposium Introduction: 2014 North American Chemical Residue Workshop," J. Agric. Food Chem., Just accepted manuscript. 2015.

[5] K. Fuji, S. Tampa, K. Shono, A. Sugie, \& A. Mori, "Murahashi Coupling Polimerization: Nickel (II)-NHeterocyclic Carbene Complex-Catalyzed Polycondensation of Organolithium Species of (Hetero)arenes," J. Am. Chem. Soc., 135 (33), 1220812211, 2013.

[6] Y. Andrei, "Introduction: Small Heterocycles in Synthesis," Chem. Rev., 114 (16), 7783, 2014.

[7] Y. Hau, S. Chang, D. Huang, X. Zhou, X. Zhu, J. Zhao, T. Chen, WY. Wong, \& WK. Wong, "Significant Improvement of Dye-Sensitized Solar Cell Performing Using Simple Phenothiazine-Based Dyes," Chem. Mater., 25 (10), 2146-2135, 2013.

[8] J. Burschca, A. Dualeh, F. Kessler, E. Baranaoff, N. Crevey-Ha, C. Yi, MK. Nazeeruddin, \& M. Grätzel, “Tris(2-(1H-pyrazol-1-yl)pyridine) cobalt (III) as pType Dopant for Organic Semiconductor and Its Application in Highly Effecient Solid-State DyeSensistized Solar Cells," Am. Chem. Soc., 133 (45), 18042-18045, 2011.

[9] V. Thottempudi, F. Foroohar, DA. Parrish, \& JM. Shreeve, "Tris(triazolo)benzene and Its Derivatives: High-Density Energetic Materials,” Angew. Chem. Int. Ed. Engl., 51 (39), 9881-9885, 2012.

[10] RM. Balabin, "Tautomeric Equilibrium and Hydrogen Shifts in Tetrazole and Triazoles: Focal-Point Analysis and ab-initio Limit, " J. Chem. Phys., 131 (154307), 18, 2009.

[11] FA. Hassan, \& KW. Younus, "Biological Evaluation of Some Azole Derivatives in Cooling Fluids (Lubricant Oils),” Res. J. Bio. Sci., 7 (1), 48-51, 2012.

[12] SP. Pardeshi, SV. Patil, R. Patil, \& VD. Bobade, "Synthesis and Antimicrobial Activities of Some 1,2,4Triazolo[3,4-b][1,3,4]thiadiazoles and 1,2,4-Triazolo [3,4-b][1,3,4]thiadiazines Bearing Bistrifluoromethyl phenyl Moiety," J. Chem. Pharma. Res., 6 (4), 675-681, 2014.

[13] AJ. Atia, \& SS. Al-Mufrgeiy, "Synyhesis and Antibacterial Activities of New 3-Amino-2-MethylQuinazolin-4(3H)-One Derivatives,” Am. J. Chem., 2 (3), 150-156. 2012.

[14] T. Taj, RR. Kamble, T. Gireesh, \& BV. Badami, “An Expeditious Green Synthesis of Schiff Bases and Azetidinones Derivatised with 1,2,4-Triazoles," J. Chem. Sci., 123 (5), 657-666, 2011.

[15] O. Bekircan, E. Menteşe, S. Ülker, \& C. Kucuk, "Synthesis of Some New 1,2,4-Triazole Derivatives Starting from 3-(4-Chlorophenyl)-5-(4methoxybenzyl)-4H-1,2,4-triazol with Anti-Lipase and Anti-Urease Activities," Arch. Pharm. Chem. Life Sci., 347, 387-397. 2014.

[16] HM. Abdullah, IK. Jassim, \& MN. Safi, "Synthesis and Characterization of New Heterocyclic Compounds with Studying Its Biological Activity," Kerbala J. Pharm. Sci., 4, 115-135, 2012.

[17] S. Sripriya1, C. Subha, \& A. Selvaraj, "The Inhibition Chemistry of 2-Amino, 5-Phenyl 1, 3, 4-Triazole for
Aluminium in Hydrochloric Acid Solution," IOSRJAC, 6 (2), 25-29, 2013.

[18] AK. Sengupta, \& M. Garg, "Studies on Potential Pestisides-Part XIV Synthesis and Biological Activities of Some New Thiosemicarbazide and Triazole Derivatives,” Def. Sci., 31 (2), 91-96, 1988.

[19] JC. Er, MK. Tang, CG. Chia, H. Liew, M. Vendrell, \& YT. Chang, "Megastockes BODIPY-triazoles as Environmentally Sensitive Turn-on Fluorescent Dyes," J. Chem. Sci., 4, 2168-2176, 2014.

[20] VN. Bulut, C. Duran, A. Gundogdu, M. Soylak, N. Yildirim, \& M. Tufekci, "A Triazole Derivatives as A New Acid-Base Indicator, " Bull. Chem. Soc. Ethiop., 24 (3), 457-460, 2010.

[21] S. Cassani, S. Kovarich, PP. Roy, L. Van der Wal, \& P. Gramatica, "Daphnia and Fish Toxicity of (Benzo)triazoles: Validated QSAR Models, and Interspecies Quantitative Activity-Activity Modeling, " J. Haz. Mat., 258-259, 50-60, 2013.

[22] AK. Singh, \& KR. Kandel, "Synthesis of Triazole Derivative: [4-(Benzylideneamino)-5-phenyl-4H-1,2,4triazole-3-thiol], " J. Nepal Chem. Soc., 30, 174-177, 2012.

[23] SMH. Al-Majidi, \& ZS. Saeed, "Synthesis and Characterization of Some New 1,2,3-Triazole, Amine Acids, Imides, and Isoimides from Ethyl-paminobenzoate and Study Their Biological Activity, ' JNUS., 16 (2), 59-69, 2013.

[24] D. Prasad, N. Aggarwal, R. Kumar, \& M. Nath, "Synthesis of Novel Heteroarenes Based [1,2,3]Triazole via Click Chemistry and Their Evaluation for Antibacterial Activity, "Indian J. Chem., 51B, 731738, 2012.

[25] SG. Agalave, SR. Maujan, \& VS. Pore, "Click Chemistry: 1,2,3-Triazoles as Pharmacophores, '” Chem. Asian J., 6, 2696-2718, 2011.

[26] JK. Sahu, S. Ganguly, \& A. Kaushik, "Synthesis of Some Novel Heterocyclic 1,2,4-triazolo [3,4-b][1,3,4] Thiadiazole Derivatives as Possible Antimicrobial Agents, ” J. App. Pharma. Sci., 4 (02), 081-086, 2014.

[27] RG. Lima-Neto, NNM. Cavalcante, RM. Srivastava, FJB. Mendonça Junior, AG. Wanderley, RP. Neves, \& JV. Dos Anjos, "Synthesis of 1,2,3-Triazole Derivatives and in Vitro Antifungal Evaluation on Candida Strains," Molecules, 17, 5882-5892, 2012.

[28] CM. Jamkhandi, \& JI. Disouza, "Evaluation of Antioxidant Activity for Some Benzotriazole Substituted with N-Phenylacetamide and Acetylcarbamic Acid Derivatives, " I. J.Pharmacy and Pharma. Sci., 5 (2), 249-253, 2013.

[29] V. Patil, W. Guerrant, PC. Chen, B. Gryder, DB. Benicewicz, SI. Khan, BL.Tekwani, \& AK. Oyelere, "Antimalarial and Antileishmanial Activities of Histone Deacetylase Inhibitors with Triazole-Linked Cap Group, ” Bioorg. Med.Chem., 18, 415-425, 2010.

[30] RC. Corrales, NB. de Souza, LS. Pinheiro, C. Abramo, ES. Coimbra, \& AD. Da Silva, “Thiopurine derivatives containing triazole and steroid: Synthesis, antimalarial and antileishmanial activities, " Biomed pharmacother., 65 (3), 198-203, 2011.

[31] OA. Naif, "Synthesis of New Benzoxadiazole Compounds Derived from Ethyl-4-(7-nitro-2,1,3,- 


\section{International Journal of Science and Research (IJSR) \\ ISSN (Online): 2319-7064}

Index Copernicus Value (2013): 6.14 | Impact Factor (2014): 5.611

benzoxadiazole-4-yl)aminobenzoate, JNUS, 15 (1), 112,2012

[32] ZAK. Al-Messri, "Synthesis of Some New 1,2,4Triazoles Derived from 2-Mercaptobenzimidazole," Um-Salama Sci. J., 6 (1), 200-208, 2009.

[33] A. Mobinikhaledi, N. Foroughifar, M. Khanpour, \& S. Ebrahimi, "Synthesis of Some Novel Schiff Bases Containing 1,2,4-Triazole Ring, " Eur. J. Chem., 1 (1), 33-36, 2010.

[34] AM. Al-Azzawi, \& KK. Hammud, "Synthesis and Characterization of Some New 1,3,4-Oxadiazole and 1,2,4-Triazole Derivatives Based on 3,4,5,6Tetrachlorophthalimide, ” Iraqi J. Sci., 54 (4), 782-788, 2013.

[35] AMN. Yahya, \& AN. Mohammad, "Synthesis of Some Fused Heterocyclic Compounds from $\alpha$-Bromo Tetralone and Indanone, " J. Raf. Sci., 21 (4), 39-48, 2010 .

[36] BA. Ahmed, \& SJ. Mohammed, "Improved Synthesis of 3-( $\alpha, \alpha$-Diphenyl- $\alpha$-hydroxymethyl) -4-amino-1,2,4triazoline -5-thione and Facile Route to 3,6Disubstituted 1,2,4-Triazolo[3,4-b][1,3,4]-thiadiazoles, " J. Raf. Sci., 20 (4), 11- 16, 2009.

[37] H. Yoshioka, H. Sakai, \& S. Shibayama, "Silver Halide Photographic Photosensitive Material and Production Method Thereof, " United States: Patent Application Publisher. 2013.

[38] SI. Koteleviskii, \& OV. Prezhdo, "Aromaticity Indices revisited: Refinement and Application to Certain FiveMembered Ring Heterocycles, " Tetrahedron, 57, 5715-5729, 2001.

[39] IB. Obot, \& AS. Johnson, "Ab initio, DFT and TDDFT Electronic Absorption Spectra Investigations on 3,5-Diamino-1,2,4-triazole, " I.B. Obot et al., Elixir Comp. Chem., 43, 6658-6661, 2012.

[40] WP. Ozimin'ski, JCz. Dobrowolski, \& AP. Mazurek, DFT Studies on Tautomerism of C5-Substituted 1,2,3Triazoles, ” J. Mol. Str., 651-653, 697-704, 2003.

[41] A. Chawla, \& P. Kaur, A Systematic "Review: Microwave Synthesis as A Part of Green Chemistry for the Synthesis of Novel 1,2,4-Triazole Derivatives, ' IRJP., 4 (1), 49-72, 2013.

[42] DC. Pinto, CM. Santos, \& AM. Silva, “Advanced NMR Techniques for Structural Characterization of Heterocyclic Structures," Recent Res. Dev. Heter. Chem., 37/661 (2), 397-475, 2007.

[43] VB. Feshin, \& EV. Feshin, "Ab initio Calculation of the Structure of 5-Chloro-1,2,4-triazole, " Chem. Heter. Comp., 37 (1), 95-99, 2001.

[44] G. Guimon, G. Pfister-Guillouzo, A. Bernardini, \& P. Viallefont, "A Photoelectron Study (Hel, Hell) of the Tautomeric Equilibrium Chloro- and Bromo-1,2,4triazole, ” Tetrahedron, 36 (8), 1071-1078, 1980.

[45] AV. Dolzhenko, G. Pastorian, \& WK. Chiu, "An Aqueous Medium Synthesis and Tautomerism Study 3(5)-Amino-1,2,4-triazole, " Tetrahedron Letters, 50 (18), 2124-2128, 2009.

[46] SC. Holam, \& BF. Straub, "Synthesis of N-Substituted 1,2,4-Triazoles: A Review, ” New J. Org. Syn., 43 (4), 319-347, 2011.

[47] E. Palaska, G. Şahin, P. Kelicen, NT. Durlu, \& G. Altinok, "Synthesis and Anti-Inflammatory of 1-
Acylthiosemicarbazide, 1,3,4-Oxadiazoles, 1,3,4 Thiadiazoles and 1,2,4-Triazole-3-thiones,"11 Farmaco, 57 (2), 101-107, 2002.

[48] K. Bahgat, \& S. Fraihat, "Normal Coordinate Analysis, Molecular Structure, Vibrational, Electronic Spectra and NMR Investigation of 4-Amino-3-phenyl-1H-1,2,4triazole-5 $(4 \mathrm{H})$-thione by $\mathrm{Ab}$ initio $\mathrm{HF}$ and DFT Method, "Spectrochimica Acta Part A: Mol. Biomol. Spectro., 135, 1145-1155, 2015.

[49] IV. Ledeţi, AA. Alexa, \& VN. Bercean, "Structural NMR Analysis of Triazolic Compounds Derived from Isonicotinic Acid, " Annals West Uni. Timisoara: Ser. Chem., 20 (1), 81-86, 2011.

[50] AA. Dippold, \& TM. Klapőtke, "Nitrogen-Rich Bis1,2,4-triazole, A Competitive Study of Structural and Energetic Properties, " Chem.-A Euro., 18 (52), 1674216753, 2012

[51] HA. Aday, "Synthesis and Characterization of the Triazole Derived from Thiosemicarbazide, 4-Amino-5phenyl-4H-1,2,4-triazole-3-thiol and Their Copper(II) and Nickel(II) Complexes, ” Eng. \& Tech. J., 31 (2), 216-221, 2013.

[52] DK. Ramesh, \& BG. Krishna, JH. Mruthyunjaya, MS. Katagi, \& G. Bolakatti, "Synthesis and Antimicrobial Evaluation of Newly Sythesized Triazolothiadiazole Analogs, ” Int. J. Drug Design Disc., 4 (2), 1050-1055, 2013.

[53] Salih NA., \& Ibraheem HA., "A New Derivatives of Benzodiazepine, Imidazole, Isatin, Maleimide, Pyrimidine and 1,2,4-Triazole: Synthesis and Characterization, " Um-Salama Sci. J., 5 (2), 305-312, 2008.

[54] FW. Askar, HA. Hassan, \& NA. Jinzeel, "Synthesis of Some Heterocyclic Compounds Derived from 2Mercapto Benzoxazole, ” J. Baghdad Sci., 10 (3), 766778, 2013

[55] CS. Hashim, \& MF. Alias, "Synthesis, Spectroscopic Study of Pt(IV), Au(III), Rh(III), Co(II) and V(IV) Complexes with Sodium[5-(p-nitro phenyl)-/4-phenyl1,2,4-triazole-3-dithiocarbamatohydrazide] and Cytotoxicity Assay on Rhabdomyosarcoma Cell Line of Heavy Metals,” J. Baghdad Sci., 9 (4), 668-679, 2012.

[56] SK. Younis, "The Use of 3-Benzylidene Phthalide as Precursor to Synthesize New 1,3,4-Oxadiazole Derivatives, " Raf. J. Sci., 22 (3), 62-75, 2011

[57] ES. El Ashry, AA. Kassem, H. Abdel-Hamid, FF. Louis, SA. Khattab, \& MR. Aouad, "Synthesis of 4Amino-5-(3-chlorobenzo[b]thien-2-yl)-3-mercapto1,2,4-triazolo[3,4-b][1,3,4]thiadiazoles and Triazolo $[3,4, b][1,3,4]$ thiadiazines Under Classical and Microwave Conditions," ARKIVOC, xiv, 119-132, 2006.

[58] C. Kavakli, PA. Kavakli, \& O. Güven, "Preparation and Characterization of Glycidyl Methylacrylate Grafted 4Amino-1,2,4-triazole Modified Nonwoven Fiber Absorbent for Environmental Application, ” Rad. Phys. Chem., 94, 111-114, 2014.

[59] S. Murtaza, MS. Akhtar, F. Kanwal, A. Abbas, S. Ashiq, \& S. Shamim, "Synthesis and Biological Evaluation of Schiff Bases of 4-Aminophenazone as An Anti-Inflammatory, Analgesic and Antipyretic Agent," J. Saudi Chem. Soc., In Press, Corrected Proof, 2014.

\section{Volume 5 Issue 3, March 2016}




\section{International Journal of Science and Research (IJSR) \\ ISSN (Online): 2319-7064}

Index Copernicus Value (2013): 6.14 | Impact Factor (2014): 5.611

[60] IK. Jassim, WKh. Jassim, S. Abd ALsatar, \& AH. Mohammed, "Synthesis and Characterization of Some New of Thiazolidine, 1,2,4-Triazole, 1,3,4-Thiadiazole, Semicarbazide, Oxazoline and A Study of Their Biological Activity, " Kerbala J. Pharma. Sci., 3, 213222, 2012.

[61] MM. Abdulrasool, AH. Jawad, \& JK. Shneine, "Synthesis, Characterization and Evaluation of Biological Activity of New Heterocyclic Compounds Containing 1,2,4-Triazole and 1,3,4-Thiadiazole Rings, Int. J. App. Sci. Tech., 2 (10), 155-164, 2012.

[62] PK. Shukla, N. Soni, A. Verma, \& AK. Jha, "Synthesis, Characterization and in vitro Biological Evaluation of A Series of 1,2,4-Triazoles Derivatives \& Triazole Based Schiff Bases, " Der Pharma Chemica, 6 (3), 153160, 2014.

[63] S. Sahoo, PK. Patwari, MCB. Kumar, \& CM. Setty, "Synthesis and Biological Activity of Certain Mannich Bases Derivatives from 1,2,4-Triazoles, " Iranian J. Pharma. Sci., 9 (4): 51-60, 2013.

[64] MGA. Al-Khuzaie, \& SMH. Al-Majidi, Synthesis, Characterization and Evaluation Antimicrobial Activity of Some New substituted 2-Mercapto-3-Phenyl-4(3H)Quinazolinone, ” Iraqi J. Sci., 55 (2B), 582-593, 2014

[65] WW. Hope, R. Lewis, \& JA. Smith, "Clinical Primer: Potential Hepatic Complications with Triazole Therapy, USA: University of Wisconsin-Madison School of Medicine and Public Health, School of Pharmacy, and School of Nursing and Fallon Medica LLC. 2010.

[66] MR. Mahmoud, WSI. Abou-Elmagd, MM. El-Shahawi, \& MH. Hekal, "Novel Fused and Spiro Heterocyclic Compounds Derived from 4-(4-Amino-5-mercapto-4H1,2,4-triazol-3-yl)phthalazin-1(2H)-one, " Eur. Chem. Bull., 3 (7), 723-728, 2014.

[67] M. Hanif, M. Saleem, MT. Hussain, NH. Rama, S. Zaib, MAM. Aslam, PG. Jones, \& J. Iqbal, "Synthesis, Urease Inhibition, Antioxidant and Antibacterial Studies of Some 4-Amino-5-aryl-3H-1,2,4-triazole-3thiones and Their 3,6-Disubstituted 1,2,4-Triazolo[3,4b]1,3,4-thiadiazole Derivatives," J. Braz. Chem. Soc., 23 (5), 854-860, 2012.

[68] IK. Jassim, AA. Fayad, \& WK. Jassim, "Synthesis and Characterization of Some Substituted Heterocyclic Compounds and Evaluation of Biological Activity," Kerbala J. Pharma. Sci., 2, 228-240, 2011.

[69] MM. Meenaxi, R. Ainapure, PB. Patil, \& AR. Bhat, "Triazolone and Their Derivatives for Anti-Tubercular Activities," Asian J. Res. Chem., 4 (7), 1050-1054. 2011

[70] YP. Hou, J. Sun, ZH. Pang, PC. Lv, DD. Li, L. Yan, HJ. Zhang, EX. Zheng, J. Zhao, \& HL. Zhu, "Synthesis and Antitumor Activity of 1,2,4-Triazoles Having 1,4Benzodioxan Fragment as A Novel Class of Potent Methionine Aminopeptidase Type II Inhibitors," Bioorg. Med. Chem., 19, 5948-5954, 2011.

[71] BA. Baviskar, SS. Khadabadi, SL. Deore, \& MR. Shiradkar, "Synthesis of clubbed Triazolyl Indeno[1,2C]Isoquinolines as an Novel Anticancer Agent, " Der Pharmacia Sinica, 3 (1), 24-30, 2012.

[72] K. Arul, \& AA. Smith, In-Silico Design, "Synthesis and in vitro Anticancer Evaluation of Some Novel 1,2,4-
Triazole Derivatives, " The Experiment, 21 (1), 14391452, 2014

[73] A. Abdul Hameed, \& F. Hassan, Synthesis, Characterization and Antioxidant Activity of Some 4Amino-5-phenyl-4H-1,2,4-triazole-3-thiol Derivatives," Int. J. App. Sci. Tech., 4 (2), 202-211. 2014

[74] MN. Mousa, \& SAN. Al-jadaan, "Evaluation of the Anti-Inflammatory Activity and Ulcerogenic Liability of 5-(3-Chloro-1-benzothien-2-yl)-4-phenyl-4H-1,2,4triazole-3-thiol,” Bas. J. Vet. Res., 11 (1), 122-127, 2012

[75] MW. Akhter, MZ. Hassan, \& M. Amir, "Synthesis and Pharmacological Evaluation of 3-Diphenylmethyl-6substituted-1,2,4-triazolo[3,4-b]-1,3,4-thiadiazoles: A Condensed Bridgehead Nitrogen Heterocyclic System," Arab. J. Chem., 7 (6), 955-963, 2014.

[76] VK. Pandey, Z. Tusi, S. Tusi, \& M. Joshi, "Synthesis and Biological Evaluation of Some Novel 5-[(3-Aralkyl amido/imidoalkyl)phenyl]-1,2,4-triazolo [3,4-b]-1,3,4thiadiazines as Antiviral Agents, "ISRN Org. Chem., 2012, 1-7, 2012.

[77] S. Jess, S. Kildea, A. Moody, G. Rennick, AK. Murchie, \& LR. Cooke, "European Union Policy on Pesticides: Implications for Agriculture in Ireland, " Pest. Mang. Sci., 70 (11), 1646-1654, 2014

[78] TP. Selby, "Heteroaryl Azole Herbicides, " United states: Patent Application Publisher, 2001.

[79] PG. Schermerhorn, \& PE. Golden, "Determination of 22 Triazole Compounds Including Parent Fungicides and Metabolites in Apple, Peach, Flour, and Water by Liquid Chromatography/Tandem Mass Spectroscopy, ' J. AOAC Int., 88 (5), 1491-1502, 2005.

[80] DVN. Rao, ARG. Prasad, YN. Spoorthy, DR. Rao, \& LK. Ravindranath, Synthesis, "Characterization and Pharmacological Studies of Sulphur Containing 1,2,4Triazole Derivatives, ” J. Taibah Uni. Med. Sci., 9 (4), 293-300, 2014.

[81] G. Singh, P. Sharma, S. Dadhwal, P. Garg, S. Sharma, N. Mahajan, \& S. Rawal, "Triazoles Impinging the Bioactivities, " Int. J. Curr. Pharm. Res., 3 (2), 105118, 2011

[82] VR. Uchil, \& V. Joshi, "Selective Reduction of Substituted $\alpha-(1,2,4-$ Triazol-1-yl)chalcones NaBH4 and Al-Isopropoxide: Synthesis of Substituted $(+) \alpha-(4-$ Chlorophenyl)- $\beta$-(phenylmethylene)-1H-1,2,4-triazole1-ethanols Having Potential Bacteriostatic and AgroBased Fungicidal Activity, " Indian J. Chem., 41B, 631-634, 2002.

[83] SR. El-Zemity, AM. El-Shazly, \& EA. Kadous, "Fungicidal and Bactericidal Potential of $(1 \mathrm{H}-1,2,4-$ Triazol-1-yl methyl)Phenols, Anilines, N-alkyl Anilines, and N,N-dialkyl Anilines," J. App. Sci. Res., 2 (12), 1314-1318, 2006.

[84] J. Tian, X. Ban, H. Zeng, J. He, Y. Chen, \& Y. Wang, "The Mechanism of Antifungal Action Essential Oil From Drill (Anethum Graveolens L.) on Aspergillus Flavus, " P40S ONE, 7 (1), 30147, 2012.

[85] Y. Tatsumi, M. Nagashima, T. Shibanashi, A. Iwata, Y. Kangawa, F. Inui, WJJ. Sin, R. Pilla, \& Y. Nishiyama, "Mechanism of Action of Efinaconazole, A Novel Triazole Antifungal Agent, " Antimicrob. Agent Chemother., 57 (5), 2405-2409, 2013.

\section{Volume 5 Issue 3, March 2016}




\section{International Journal of Science and Research (IJSR) \\ ISSN (Online): 2319-7064}

Index Copernicus Value (2013): 6.14 | Impact Factor (2014): 5.611

[86] AD. Panchal, PD. Kunjadia, \& PM. Patel, "Synthesis and Biological Evaluation of Chalcone Derivatives Linked Triazoles, " Int. J. Pharma. Sci. Drug Res., 3 (4), 331-337, 2011.

[87] M. Suresh, SB. Jonnalagadda, \& CV. Rao, "Synthesis of (Z)-2-(4-Substitutedbenzylidene)-7-isocyano-3,6dioxo-8-phenyl-3,6-dihydro-2H-thiazolo- [3',2':2,3] $[1,2,4]$ triazolo[1,5-a]pyridine-9-carbonitrile, " Oriental J. Chem., 27 (1), 127-133, 2011.

[88] J. Ferlay, I. Soerjomataram, M. Ervik, R. Dikshit, S. Eser, C. Mathers, M. Rebelo, DM. Parkin, D. Forman, \& F. Bray, "GLOBOCAN 2012 v1.0, Cancer Incidence and Mortality Worldwide: IARC Cancer Base No. 11, Lyon, France: " International Agency for Research on Cancer, 2013

[89] X. Li, XQ. Li, HM. Liu, XZ. Zhou, \& ZH. Shao, "Synthesis and Evaluation of Antitumor Activities of Novel Chiral 1,2,4-Triazole Schiff Bases Bearing $\gamma$ Butenolide Moiety, " Org. Med. Chem. Lett., 2 (26), 15, 2012

[90] B. Jiang, X. Huang, H. Yao, J. Jiang, X. Wu, S. Jiang, Q. Wang, T. Lu, \& J. Xu, "Diaryl-1,2,4-Triazoles Bearing N-Hydroxyurea Moiety as Dual Inhibitors of Cyclooxygenase-2 and 5-Lipoxygenase, ” Org. Biomol. Chem., 12 (13), 2114-2127, 2014.

[91] J. Subbarao, S. Vidhyadhara, \& N. Srinivasulu, "Antimicrobial and Antiinflammatory ACctivities of Some Novel Triazolothiadiazoles, Int. J. Pharm., 4 (1), 304-308, 2014.

[92] Y. Murti, R. Agnihotri, \& D. Pathak, Synthesis, Characterization and Pharmacological Screening of Some Substituted 1,2,3- \& 1,2,4-Triazoles, " American J. Chem., 1 (2), 42-46, 2011.

[93] E. Chornicle, \& W. Mulleners, "Anticonvulsant Drugs for Migrain Prophylaxis, " Cochrane Database Syst. Rev., 3, CD003226, 2004.

[94] PB. Wingrove, KA. Wafford, C. Bain, \& PJ. Whiting, "The Modulatory Action of Loreclezole at the $\gamma$ Aminobutyric Acid Type A Receptor is Determined by a Single Amino Acid in the $\beta 2$ Subunit, " Proc. Nat. Sci., USA, 91, 4569-4573, 1999.

[95] T. Plech, B. Kaproń, JJ. Łuszczki, M. Wujec, A. Paneth, A. Siwek, M. Kołaczkowski, M. Żołnierek, \& G. Nowak, "Studies on the Anticonvulsant Activity and Influence on GABA-ergic Neurotransmission of 1,2,4Triazole-3-thione-Based Compounds, " Molecules, 19, 11279-11299, 2014.

[96] R. Singh, \& A. Chouhan, "Important Methods of Synthesis and Biological Significance 1,2,4-Triazole Derivatives," WORLD J. PHARMACY PHARMA. SCI., 3 (8), 874-906, 2014.

[97] E. Thomas, MG. Ghany, \& Liang TJ., "The Application and Mechanism of Ribavirin in Therapy of Hepatitis C, " Antiviral Chem. Chemother., 23, 1-12, 2012.

[98] K. Benci, T. Suhina, L. Mandić, SK. Pavelić, Paravić AT., K. Pavelić, J. Balzarini, K. Wittine, \& M. Mintas, "Novel 1,2,4-Triazole and Purine Acyclic Cyclopropane Nucleoside Analogues: Synthesis, Antiviral and Cytostatic Activity Evaluation, " Antiviral Chem. Chemother., 21, 221-230, 2011.

[99] SM. El-Feky, LA. Abou-zeid, MA. Massoud, SG. Shokralla, \& HM. Eisa, "Synthesis, Molecular
Modeling of Novel 1,2,4-Triazole Derivatives with Potential Antimicrobial and Antiviral Activities, " Acta Pharma. Sci., 52, 353-364, 2010.

[100] VS. Wakale, SR. Pattan, \& V. Tambe, "Therapeutic Importance of 1,2,4-Triazole, " A Review, Int. J. Res. Pharma. Biomed. Sci., 4 (3), 985-1001, 2013.

[101]M. Asif, A Brief Review on Antitubercular Activity of Pharmacological Active Some Triazole Analogues," GJRR, 1 (3), 51-58, 2014.

[102]HO. Elansary, "Natural Antioxidants and their Role against Human Cancer, ” J. Plant Biochem. Physiol., 2 (2), 1000e125, 2014

[103]K. Sancak, Y. Ünver, D. Ünlüer, E. Düğdü, G. Kőr, F. Çelic, \& E. Birinci, "Synthesis, Characterization, and Antioxidant Activities of New Tri-Substituted Triazoles, " Turk. J. Chem., 36, 457-466, 2012.

[104]KD. Dobbs, J. Feldman, WJ. Marshall, SJ. McLain, JS. Meth, GD. Vo, \& Y. Wang, "Phosphorescent Iridium(III) Complexes of Cyclometalated 5-Aryl-1H1,2,4-Triazole Ligand Structural, Computational, Spectroscopic, and Device Studies, " J. Phys. Chem. C., 118 (48), 27763-27771, 2014.

[105]RM. Izatt, GC. Lindh, RL. Bruening, P. Huszthy, CW. McDaniel, JS. Bradshaw, \& JJ. Christensen, "Separation of Silver from Other Metal Cations Using Pyridone and Triazole Macrocycles in Liquid Membrane Systems,” Anal. Chem., 60 (17), 1694-1699, 1988.

[106]M. Gudelj, GO. Fruhwirth, A. Paar, F. Lottspeich, KH. Robra, A. Cavaco-Paulo, \& Gübitz GM., "A CatalasePeroxidase from a Newly Isolated Thermoalkaliphilic Bacillus sp.with Potential for the Treatment of Textile Bleaching Effluents," Extremophiles, 5, 423-429, 2001.

[107]IA. Gad El-Karim, MS. Amine, AA. Mahmoud, \& AS Gouda, "Fatty Acids in Heterocyclic Synthesis. Part XIV: Synthesis of Surface Active Agents from Some Novel Class of Oxadiazole, Thiadiazole and Triazole Derivatives Having Microbiological Activities," J. Surfact. Deterg., 17 (3), 509-523, 2013.

\section{Author Profile}

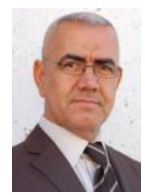

Jawad Shneine received the B.S. and M.S. degrees in Chemistry from Baghdad University and RWTH Aachen University in 1986 and 1995, respectively. He accomplished his $\mathrm{PhD}$ degree at the Institute of Biochemistry of RWTH Aachen University, Germany in 1999. He continued there a research project for further two years. Since 2005 he is a teaching and research member of the Chemistry Department of the Science faculties of the Al-Nahrain University in Baghdad - Iraq. 